\title{
IAMJ
}

INTERNATIONAL

AYURVEDIC

MEDICAL JOURNAL

\section{AN AYURVEDIC MANAGEMENT OF ALCOHOLIC LIVER DISEASE W.S.R TO SHAKHASHRITA KAMALA - A CASE STUDY}

\author{
Samata $^{1}$, Shaila Borannavar ${ }^{2}$, Ananta S Desai ${ }^{3}$ \\ ${ }^{1}$ PG Scholar, PG Studies Dept of panchakarma Govt. Ayurveda Medical College, Bengaluru, Karnataka, India \\ ${ }^{2}$ Associate Professor, PG Studies department of Panchakarma Govt. Ayurveda Medical College, Bengaluru, \\ Karnataka, India \\ ${ }^{3}$ Professor and HOD, PG Studies Department of Panchakarma, Govt Ayurveda Medical College, Bengaluru, \\ Karnataka, India
}

Corresponding Author: samatavaidurya123@gmail.com

\section{https://doi.org/10.46607/iamj3709112021}

(Published Online: November 2021)

Open Access

(C) International Ayurvedic Medical Journal, India

Article Received:23/10//2021 - Peer Reviewed:05/11/2021 - Accepted for Publication:06/11/2021

\section{Check for updates}

\begin{abstract}
Alcoholic liver disease is a pathological condition of the liver parenchymal tissue due to excessive consumption of alcohol over a long period of 6-10 years or even earlier. Here in we present a case of a married male of $35 \mathrm{yr}$. old reported in the Panchakarma OPD of SJIIM Government Ayurveda Medical College Bengaluru on 30 ${ }^{\text {th }}-J a n-$ 2021, with chief complaints of swelling in the bilateral lower limbs, deep yellowish and burning micturition, yellowish discoloration of sclera, reduced appetite, nausea and generalized weakness in the body since 3 months, with the increased level of LFT and USG-abdomen report suggesting hepatomegaly with fatty changes, was examined and diagnosed as alcoholic liver disease and treated with Amapachana with Trikatu Churna, Nitya Virechana with Chitraka Haritaki Leha fallowed by Mustadi Yapana Basti had shown a very good improvement in normalizing appetite, bilateral lower limb swelling and deep yellow micturition. Total bilirubin, SGOT and ALP values were reduced.
\end{abstract}

Keywords: Alcoholic Liver disease, Shakhashrita Kamala, Nitya Virechana 


\section{INTRODUCTION}

Alcoholic liver disease is a pathological condition of the liver which is used to describe a spectrum of liver injury and it includes alcoholic fatty liver with or without hepatitis, alcoholic hepatitis to cirrhosis. The main cause is excessive consumption of alcohol over a long period of time about 10yr in a large quantity, causing liver toxicity by parenchymal tissue damage. Due to alcohol, the skill of intellect, sensation, perception, and physiological activities of the body like digestion, absorption and metabolism which are necessary over course of a lifetime, and which cause in and out the development of humans are mainly hampered. ALD is an emerging public issue globally and its burden is increasing worldwide vigorously. The ALD patient's condition is once comprehensible and manageable later is transformed into an intimidating and rancorous environment. Alcohol is one of the commonest causes of end-stage liver disease with $50 \%$ of cirrhosis related mortality being attributed directly to alcohol and it is the world's largest risk factor for disease burden. Consumption of alcohol results in 2.5 million deaths each year ${ }^{1}$. In India, alcohol is the commonest cause of cirrhosis (34.3\%) and almost $20 \%$ of all liver disease (irrespective of aetiology) are current alcohol consumers ${ }^{2}$.Hepatobiliary anomaly is not a disease but is a heterogeneous group of disorders. ALD is one of the most frequent clinical presentations of this group. It has been rising in India since the adaptation of foreign culture, poverty etc.

ALD morphologically can be divided into 3 stages -

A) Alcoholic steatosis (fattyliver) often presents as asymptomatic hepatomegaly and mild elevation in the biochemical liver test.

B) Clinical presentations of Alcoholic hepatitis range from asymptomatic to severe liver failure with jaundice, ascites, GI bleeding, typically anorexia, nausea, vomiting, fever, tender hepatomegaly.

C) Cirrhosisis the end stage of liver failure with irreversible changes.

Stages of ALD can be closely interpreted with Kamala leading to Jaloudara manifestation. Acharya Charaka in Chikitsa Sthana $16^{\text {th }}$ chapter of Panduro- ga chikitsaadhyaya have mentioned the cause as the vitiation of Pitta along with its symptoms, they are yellowish discolouration of eyes, skin, face, urine, burning micturition, indigestion, generalized weakness, anorexia and lean body ${ }^{3 a}$. Again, it has been classified as Shakhashrita and Koshtashrita Kamala based on the Vyadhi Avastha (disease stage). Treatment given is the removal of Margavarodha followed by Pittahara Chikitsa ${ }^{3 \mathrm{~b}}$ and Virechana Respective$1 \mathrm{y}^{3 \mathrm{c}}$.ALD is always seen as a complication of alcoholism. It produces a very miserable and dependent crippled life. If he or she is the only earning member, then the family must face endless problems. In these conditions if any help is extended to the sufferers, it will be a great advantage to the patient, a good credit to the physician and in turn to the science itself. In the contemporary system of medicine administration of multivitamins, corticosteroids, in later stages para surgical and surgical measures are taken. With the advancement of modern drugs, the view of disease has grossly changed. Therefore, Ayurvedic therapeutics had attracted considerable glamour for providing safe and effective remedies. Numerous research has been done time and again to reprove the worth of these medications. Considering all the above points, here in presenting this single case study to find a measure that could help in ALD patients.

\section{CASE REPORT:}

The present case is about the Ayurvedic management of ALD i.e., Shakhashrita Kamala. A 35-year-old male suffering from ALD reported to Panchakarma outpatient department (OPD) of SJIIM hospital, Bengaluru with chief complaints-

- swelling in $\mathrm{B} / \mathrm{L}$ lower limbs,

- yellowish discolouration of eyes, skin and dark urine with burning micturition,

- Clay-coloured stool associated with reduced appetite,

- Anorexia, nausea and disturbed sleep

- Tremors were seen as symptoms of alcohol withdrawal for 3-months 
Associated Complaints: Generalized weakness in the body for 1 month

\section{HISTORY OF PRESENT ILLNESS}

He was a known alcoholic for 18 years, (Once weekly up to 10yrs), used to consume approximately $180 \mathrm{ml}$ per day till 2018 and after that, he started to take 550-750 ml with spicy food items. In the year 2018, he had developed Jaundice along with severe vomiting and mild tremors in the B/L UL. For this, he got treated from a private hospital and the Patient got relief but restarted alcohol intake after one month. Again, in December 2020he developed the abovementioned symptoms and approached a local physician with these symptoms and was diagnosed with alcoholic hepatitis and treated for 10 days with a standard of care. As the complaints were not satisfactorily reduced, he opted for the Ayurvedic treatment. He was admitted in February for 34days.

\section{Personal History:}

Name- XYZ

Age- 35 years

Gender - Male

Marital status- Married

Occupation- Cab driver

Weight $-60 \mathrm{~kg}$
Bala- Avara

Sleep- Disturbed

Addiction- Alcohol and tobacco

Bowel habit- Irregular

Appetite- Reduced

\section{CLINICAL FINDINGS- PHYSICAL EXAMINATION:}

\section{ASHTA VIDHA PAREEKSHA}

- Nadi: Pittaja Nadi / 86/min

- Mutra: Peeta Varna

- Mala: Tilapishtha Nibha (clay-coloured)

- Jiwha: Lipta
- Shabda: Prakrita

- Sparsha: Anushna sheeta

- Druk: Peeta varna

- Akriti: Madhyama

\section{DASHAVIDHA PAREEKSHA}

- Prakriti: Pitta Vata

- Aharaja Hetu: Madya sevana

- Viharaja Hetu: Atiyana

- Manasika Hetu: Krodha, Dukhah, Chinta

- Dosha: Pitta and Rakta

- Dushya: Rakta and Mamsa

- Swabhava: Chirakari

- Desha: Anoopa

- Kala: Shishira

- Sara: Madhyama

\section{GENERAL EXAMINATION}

- Icterus +++, yellowish discolouration of oral mucosa, nasal mucosa, skin, P/A - no organomegaly, mild tenderness, pitting oedema on B/L LL and slight puffiness of the face,
- Samhanana: Madhyama

- Pramana: Madhyama

- Satmya: Madhyama

- Satva: Madhyama

- Ahara shakthi:

A) Abhyavaharana shakthi: Avara

B) Jarana shakthi: Avara

- Vyayama shakthi:

A)Poorvakaleena: Pravara

B) Adhyatanakaleena: Avara

- Vaya: Madhyama/35yr

- Bala: Avara

\section{SYSTEMIC EXAMINATION}

- CVS-S1 S2 heard. No added sounds.

- Respiratory system: Lungs clear

- CNS-Conscious \& well oriented to time \& place, irritation and anger was present, memory was in- 
tact, Romberg sign was positive, had slurred speech.

- muscle power: $4 / 5$ - all the limbs, muscle tone: normotonic, gait- ataxic gate, involuntary movements-action tremors

reflexes: normal

\section{Gastrointestinal tract examination}

Lower GI Tract: Per abdominal examination on inspection, it was normal, on palpation there was mild tenderness over the right hypochondriac region, percussion and auscultation could not elicit anything.

Ultrasonography abdomen impression: Hepatomegaly with fatty changes. (19/12/2019)

\section{Investigations:}

\section{Liver function test}

\begin{tabular}{|l|l|l|l|}
\hline LFT & $\mathbf{2 1 / 1 2 / 2 0 1 9}$ & $\mathbf{3 0 / 0 1 / 2 1}$ & $\mathbf{1 5 / 2 / 2 1}$ \\
\hline Total bilirubin & $1.1 \mathrm{mg} / \mathrm{dl}$ & $5.6 \mathrm{mg} / \mathrm{dl}$ & $3.32 \mathrm{mg} / \mathrm{dl}$ \\
\hline Direct bilirubin & $0.2 \mathrm{mg} / \mathrm{dl}$ & $2.7 \mathrm{mg} / \mathrm{dl}$ & $2.7 \mathrm{mg} / \mathrm{dl}$ \\
\hline Indirect bilirubin & $0.9 \mathrm{mg} / \mathrm{dl}$ & $2.9 \mathrm{mg} / \mathrm{dl}$ & $0.62 \mathrm{mg} / \mathrm{dl}$ \\
\hline SGOT & $91 \mathrm{U} / \mathrm{L}$ & ----- & $82 \mathrm{U} / \mathrm{L}$ \\
\hline SGPT & $67 \mathrm{U} / \mathrm{L}$ & ---- & $43 \mathrm{U} / \mathrm{L}$ \\
\hline ALP & $345 \mathrm{U} / \mathrm{L}$ & ---- & $105 \mathrm{IU} / \mathrm{L}$ \\
\hline Total protein & $12.9 \mathrm{~g} / \mathrm{dl}$ & ---- & $11.1 \mathrm{~g} / \mathrm{dl}$ \\
\hline Albumin & $4.4 \mathrm{~g} / \mathrm{dl}$ & ---- & $3.5 \mathrm{~g} / \mathrm{dl}$ \\
\hline Globulin & $8.5 \mathrm{~g} / \mathrm{dl}$ & ---- & $7.6 \mathrm{~g} / \mathrm{dl}$ \\
\hline
\end{tabular}

\section{TREATMENT SCHEDULE:}

The patient got admitted on 2/2/2021, initially, he was given Trikatu Churna and Arogya Vardhini Rasa for 18days, Gokshuradi Guggulu for 10 days, after passing normal coloured stools he was given Chitraka Haritaki Leha as Nitya Virechana for 6 days followed by Mustadi Yapana Basti for 8days in Kala
Basti pattern. The patient was discharged on 8/03/2021 and had 2 follow ups in the next 30 days. During the treatment and follow up, the patient was completely on cessation of alcohol. Throughout the treatment, as a part of Pathya the patient was advised to avoid spicy, oily and salty food.

\begin{tabular}{|c|c|c|}
\hline Date & Medicine & Dose \\
\hline $2-26 / 2 / 2021$ & $\begin{array}{l}\text { Arogya Vardhini Rasa } \\
\text { Trikatu Churna } \\
\text { Draksharishtha }\end{array}$ & $\begin{array}{l}2-2-2(\mathrm{~A} / \mathrm{F}) \\
1 / 2 \mathrm{tsp}-0-1 / 2 \operatorname{tsp}(\mathrm{B} / \mathrm{F}) \\
15 \mathrm{ml}-0-15 \mathrm{ml}(\mathrm{A} / \mathrm{F})(\text { Ushna Jala Anupana })\end{array}$ \\
\hline $5-15 / 2 / 2021$ & Gokshuradi guggulu & 1-1-1 (A/F) (Ushna Jala Anupana) \\
\hline $20 / 2 / 2021$ & passed normal stools & \\
\hline $21-26 / 02 / 2021$ & Chitraka Haritaki Lehya & (1tsp -0-1tsp A/F) (Ksheera Anupana) \\
\hline $28 / 2-7 / 3 / 2021$ & Mustadi Yapana Basti & Kala basti pattern \\
\hline \multicolumn{3}{|l|}{ Shamanoushadi } \\
\hline $8 / 03-10 / 04 / 2021$ & $\begin{array}{l}\text { Arogya vardhini Rasa } \\
\text { Patola Katurohinyadi } \\
\text { Kashaya } \\
\text { Draksharishtam } \\
\text { Ashwagandha Churna }\end{array}$ & $\begin{array}{l}1-0-1(\mathrm{~A} / \mathrm{F}) \\
10 \mathrm{ml}-0-10 \mathrm{ml}(\mathrm{A} / \mathrm{F}) \\
15 \mathrm{ml}-0-15 \mathrm{ml}(\mathrm{A} / \mathrm{F})(\text { Ushna Jala Anupana }) \\
2 \mathrm{tsp}-0-2 \mathrm{tsp}(\mathrm{B} / \mathrm{F})(\text { Ksheera Anupana })\end{array}$ \\
\hline
\end{tabular}




\section{RESULTS:}

\begin{tabular}{|l|l|l|l|}
\hline SL & SYMPTOMS & BEFORE TREATMENT & AFTER TREATMENT \\
\hline 01 & Haridrata of netra (yellowish discolouration of sclera) & 2 & 0 \\
\hline 02 & Haridrata of Tvak (yellowish discolouration of the skin) & 2 & 0 \\
\hline 03 & Dourbalya(weakness) & 3 & 1 \\
\hline 04 & Peetata of Mutra (yellowish discolouration of urine) & 3 & 0 \\
\hline 05 & Aruchi (Anorexia) & 3 & 1 \\
\hline 06 & Hrullasa (Nausea) & 2 & 0 \\
\hline
\end{tabular}

\section{ASSESSMENT CRITERIA OF SHAKHASHRITA KAMALA}

\begin{tabular}{|l|l|l|l|l|l|}
\hline SN & SYMPTOMS & NORMAL & MILD & MODERATE & SEVERE \\
\hline 01 & $\begin{array}{l}\text { Haridrata of netra (yellowish discolouration } \\
\text { of sclera) }\end{array}$ & 0 & 1 & 2 & 3 \\
\hline 02 & $\begin{array}{l}\text { Haridrata of Tvak (yellowish discolouration } \\
\text { of skin) }\end{array}$ & 0 & 1 & 2 & 3 \\
\hline 03 & $\begin{array}{l}\text { Dourbalya (weakness) } \\
\text { Peetata of Mutra (yellowish discolouration of } \\
\text { urine) }\end{array}$ & 0 & 1 & 2 & 3 \\
\hline 04 & Aruchi (Anorexia) & 0 & 1 & 2 & 3 \\
\hline 05 & Hrillasa (Nausea) & 0 & 1 & 2 & 3 \\
\hline
\end{tabular}

\begin{tabular}{|l|l|l|}
\hline LFT & $\mathbf{1 5 / 2 / 2 1}$ & $\mathbf{5 / 3 / 2 0 2 1}$ \\
\hline Total bilirubin & $3.32 \mathrm{mg} / \mathrm{dl}$ & $1.91 \mathrm{mg} / \mathrm{dl}$ \\
\hline Direct bilirubin & $2.7 \mathrm{mg} / \mathrm{dl}$ & $1.79 \mathrm{mg} / \mathrm{dl}$ \\
\hline Indirect bilirubin & $0.62 \mathrm{mg} / \mathrm{dl}$ & $0.12 \mathrm{mg} / \mathrm{dl}$ \\
\hline SGOT & $82 \mathrm{U} / \mathrm{L}$ & $64 \mathrm{U} / \mathrm{L}$ \\
\hline SGPT & $43 \mathrm{U} / \mathrm{L}$ & $40 \mathrm{U} / \mathrm{L}$ \\
\hline ALP & $105 \mathrm{IU} / \mathrm{L}$ & $88 \mathrm{IU} / \mathrm{L}$ \\
\hline Total protein & $11.1 \mathrm{~g} / \mathrm{dl}$ & $10.08 \mathrm{~g} / \mathrm{dl}$ \\
\hline Albumin & $3.5 \mathrm{~g} / \mathrm{dl}$ & $3.18 \mathrm{~g} / \mathrm{dl}$ \\
\hline Globulin & $8.5 \mathrm{~g} / \mathrm{dl}$ & $-\cdots$ \\
\hline
\end{tabular}

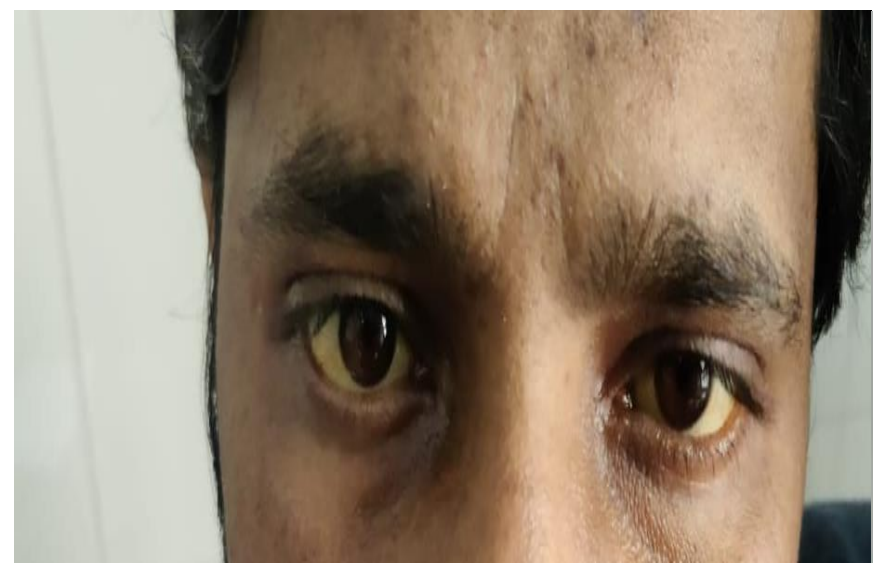

BT

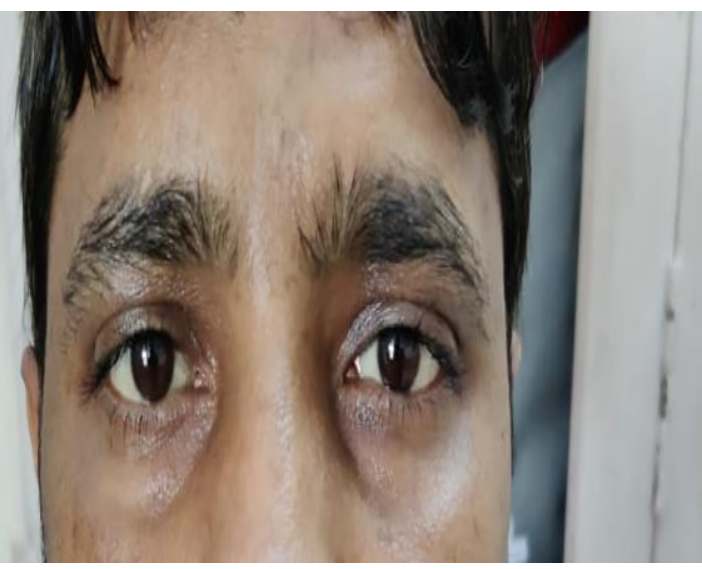

AT 


\section{DISCUSSION}

Madya directly vitiates the Yakrut because of its Guru Gunas like Vyavayi, Vikasi etc. the contemporary literature also says that alcohol metabolites are responsible for liver cells damage and altered liver functions and we get striking similarities in the Samprapti of both sciences. Based on the patient's complaints, examination and laboratory investigations, it was diagnosed as alcoholic liver disease in $2^{\text {nd }}$ stage i.e., alcoholic hepatitis. In Ayurveda, it can be considered as Shakhashrita Kamala because of obstructive mechanism (intra-hepatic) in the pathogenesis. Line of treatment told for Shakhashrita Kamala by Acharya Charaka was adopted in the study ${ }^{3 \mathrm{~d}}$. Trikatu Churna $^{3 \mathrm{e}, 5}$ as Amapachaka and to improve Aruchi and Hrullasa, Arogyavardini Rasa 6 to remove Margavarodha (Intra hepatic) as it contains Katuki, it doses the Bhedana of Malas which has blocked the pathway of Pitta reaching Koshtha. Both the medicines were given until the patient acquired normal colored stools ("Aapitta Raagaat Shakrito"). Draksharishtham ${ }^{7}$ was given for Balya and Malashodhanartha and to minimize forthcoming Alcoholic withdrawal syndromes because the patient had abruptly stopped alcohol intake. Gokshuradi Guggulu 8 was given for Shotha in B/L lower limbs, having properties of Shothahara and Mutrala thus it is helpful to increase urine output in reducing oedema. After the removal of Margavarodha and by considering Pitta has reached the Koshta, Nitya Virechana was adopted by Chitraka Haritaki Leha ${ }^{9}$ and Ksheera as Anupana(250ml). As patient's Bala was very less, classical Virechana was not selected. Chitraka Haritaki Leha is mainly advised in respiratory conditions, even though it has been selected here because of its ingredients. Chitrka Haritaki Leha does Agni Deepana, Amapachana and Vatanulomana hence acting best in this present case by mainly relieving Aruchi, Hrullasa and Nitya Virechana acting on Pitta Dosha. After this betterment was seen in reducing the symptoms of yellowish bulbar conjunctiva and yellowish urine and this indicates the Pitta Dosha Shamana. After 2 days of Nitya Virechana, Mustadi Yapana Basti ${ }^{9}$ was Given for 8 days in the Kala Basti pattern. Yapana Basti is very helpful in the present case because of its Sadyobalajanana property as the patient was Durbala. It also acts as Rasayana.

\section{CONCLUSION}

Broadly Alcoholic Liver Disease can be said as Raktavaha Srotomula Dushti. All types of Madya(alcohol) can cause Rakta Dushti thereby causing Yakrutvikara (Liver disease) if consumed inappropriately. Alcohol not only affects the health of the individual but also causes social, economic and personal hazards. Alcoholic Liver Disease can be considered as Shakhashrita Kamala in Ayurveda. Treatment is given in the present study-Amapachana, Nitya Virechana, Mustadi Yapana Basti, other Shamanoushadis and Pathya had shown significant results in managing the altered LFT and ALD by breaking the Samprapthi

\section{REFERENCES}

1. https://www.who.int/substance_abuse/publications/glo bal_alcohol_report/msb_gsr_2014_1.pdf

2. https://www.who.int/substance_abuse/publications/glo bal_alcohol_report/msb_gsr_2014_1.pdf

3. Agnivesha. Charaka Samhita- revised by Charaka Dridabala, with Ayurveda Dipika commentary of Chakrapanidatta edited by Vaidya Yadavji Trikamji Acharya, Varanasi: Chowkhamba Orientalia; reprint 2010.Pp738. a) Chi. 16/35-36. Pn6528.b) Chi. 16/128131. Pn6532, c) Chi. 16/40. Pn6528d) Chi. 16/130131. Pn532, e) Chi. 16/129. Pn6532

4. Dennis L. Kasper- Harrison's manualof medicine editedby Dennis L. Kasper MD, Anthony S. Fauci, Stephen L. Hauser, Dan L. Longo, Larry Jameson, Joseph Loscalzo, 19th edition. Mc Graw Hill Education 2006. Pp 1381, pn828.

5. BaishyaRuplal, BhavprakashNighantu, Part1, Varanasi, Chaukhamba Sanskrit Samsthan, Haritakyadivarga, sloka 64-65, page 19.

6. Tripathi Indradev. Rasaratna Samuchchaya. 20/86-92, 3rd ed., Varanasi; Chaukhambha Sanskrit Bhawan; 2006.p. 252.

7. Sarangadhara Samhita, jiwanaprabha Hindi commentary by Dr. Smt. Shailajasrivastava, Madhyamakhanda, 10th chapter Asava Aristadi Sandhana. sloka no-69 to 72, 2nd edition, Chaaukhamba Orientalia Varanasi, 1998; p.253 
8. Sarangadhara Samhita, jiwanaprabha Hindi commentary by Dr. Smt. Shailajasrivastava, Madhyamakhanda, 7th chapter. sloka no849 to 87 , 2nd edition, Chaaukhamba Orientalia Varanasi, 1998; p.233.

9. Anonymous. The Ayurvedic Formulary of India. Ministry of health and family welfare. Dept. of Indian systems of medicine and Homeopathy: New Delhi; 2004. p. 10.

\section{Source of Support: Nil \\ Conflict of Interest: None Declared}

How to cite this URL: Samata et al: An Ayurvedic Management of Alcoholic Liver Disease - A Case Study W.S.R To Shakhashrita Kamala. International Ayurvedic Medical Journal \{online\} 2021 \{cited November 2021\} Available from: http://www.iamj.in/posts/images/upload/2870_2876.pdf 